平成 2 年レーザー学会学術講演会第10回年次大会

26 p I 1

$$
\begin{aligned}
& \text { K r Fレーザージ゙による } \\
& \text { ターがットプラズマの特性 }
\end{aligned}
$$

電通大・新形レーザー

米田仁紀、新井達也、木村孝行、幸喜俊、寺田朋生、

三浦隆博、村谷正之、植田㥶一、宅間宏

$\mathrm{Kr} \mathrm{F}$ rーザーの波長 $250 \mathrm{~nm}$ 光とターゲットとのカップリングは、臨界密度 が高い、 $\mathrm{x}$ 線への輻射変换効事が高い等の理由で、非常に俊れていると考えられてい る。しかし、この波長でのターゲット実験は少なく、特に n $\mathrm{s}$ 以上の長パルス、 $\mathrm{p} \mathrm{s}$ 以下の短パルス領域では、実験がほとんど行われていない。

そこで、我々は、本センターにある大出力のモジュール型ＫｒＦレーザーシステム を用い、ターゲット実験を行ったのでこれについて報告する。

現有のシステムは、 $500 \mathrm{f} \mathrm{s}$ から $20 \mathrm{n} \mathrm{s}$ までパルス幅を変化させることが可能 であり、1 $10^{13} \mathrm{~W} / \mathrm{c} \mathrm{m}^{2} \sim 10^{16} \mathrm{~W} / \mathrm{c} \mathrm{m}^{2}$ の照射条件が設定できる。計測は、敢乱 光の强度分布をミニカロリメータで、ターゲットからの $\mathrm{x}$ 線輻射特性をピンホールカ メラ、空間分解を持った結晶分光器（ $\mathrm{PET}, \mathrm{KAP}$ )、マルチフィルター $\mathrm{x}$ 線ダ オード、透過型回折分光器で行った。

图 1 は、A lをターゲットにして $20 \mathrm{n} \mathrm{s}, 10{ }^{14} \mathrm{~W} / \mathrm{c} \mathrm{m}^{2}$ の照射条件下で、散 乱光の角度分布を観揤した結果である。散乱光エネルギーのほとんどが、f $\mathrm{f} / 2$ の収 束レンズ内に散乱されていることが分かる。また、総合的な吸収事は $99 \%$ 以上であ

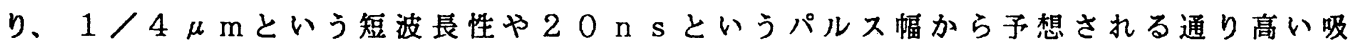
収率を示していた。

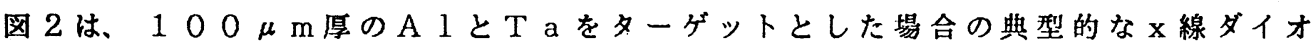
一ドの波形である。A 1 では、 $\mathrm{x}$ 線強度の時間履歴

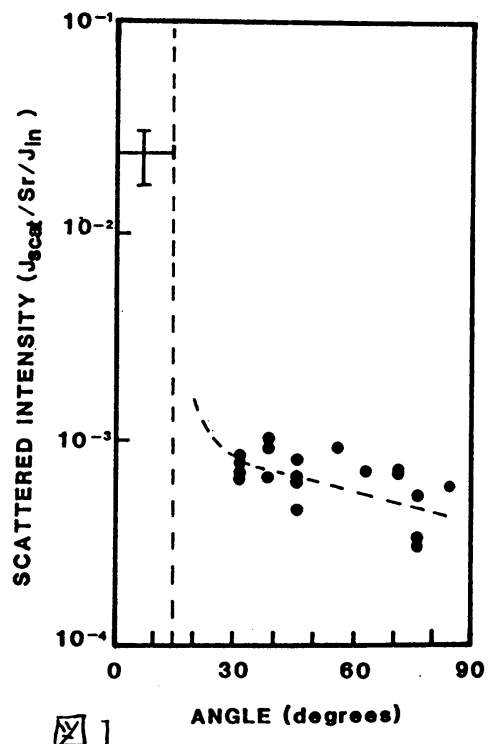
が、レーザー光の波形にほぼ等しい結果であるのに 対し、Taでは、 $20 \mathrm{~ns}$ 的パルス幅内で強度が大 きく変化していることが観测されている。、譜演で は、他の $\mathrm{x}$ 線輻射特性の観测結果を合わせてこれ ら実験結果の検討を行う子定である。

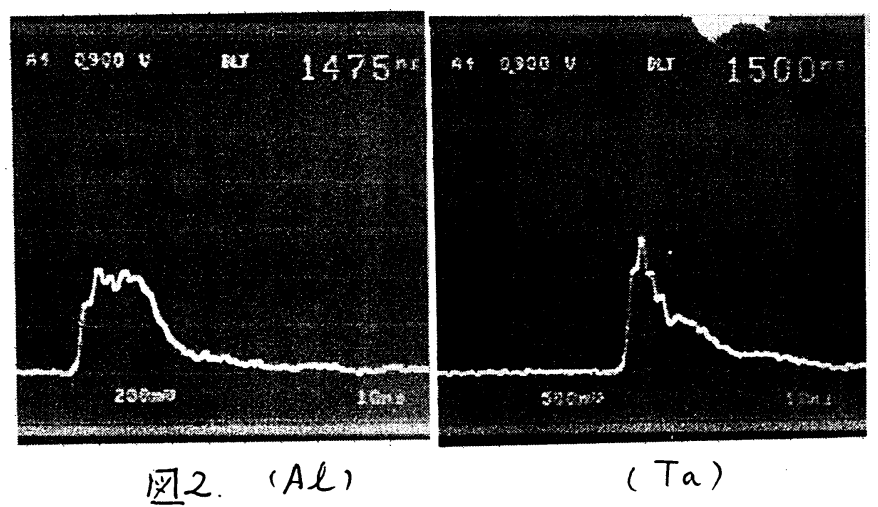




\section{$26 \mathrm{p} I 2$}

超高強度ビコ秒レーザー生成ブラズマからのX線発生

○西尾匡弘山川考一白神宏之加藤義章 中井貞雄山中千代衛 ${ }^{\mathrm{A}}$

$$
\text { （阪大レーザー研 Aレーザー総研） }
$$

高強度短バルスレーザーの発生研究が進み、短バルスレーザーと物筫との相互作用 の解明や短バルスX線発生源の実現などを目的としたターダット照射実験が開始され ている。

現在我々は、チャープパルス増幅による光パルス压縮法を用いて波長 1 ．０5 4 m、 パルス幅 4 p s、エネルギー $5 \mathrm{~J}$ の高強度短バルスレーザーを得ている。

前回実験では、压縮パルスに付随する背景光（ペデタル）が短パルス光に先立っ て希薄ブラズマを生成することが問題となった。そこで今回、可飽和吸収体を用いて ペデスタルを除去することによって（2）固体と短バルスレーザーとの相互作用に関 する実験を可能にし、厚さ50 5 mのA 1 平板ターゲットにこの短バルス光を照射し、 生成されたブラズマから発生するX線を钼測した。照射強度は約 $10^{17} \mathrm{~W} / \mathrm{c} \mathrm{m}^{2}$ で ある。

図 1 は、X線結晶分光器で観測された $\mathrm{A} 1$ のX線スペクトルである。これらのX線 スペクトルからブラズマの電子温度、電子密度、電離度などを評価し、ブラズマの状 熊を推定する。また、ペデスタルの除去を行なっていない短パルス光、あるいはパル ス幅 $100 \mathrm{ps}$ 、エネルギー $20 \mathrm{~J}$ の長パルス光を照射し比較を行なっている。さら に、ターグットの原子番号Zを变えることで、より広笛囲にわたる温度、密度領域の 計测を試みた。

（1）西尾他、1989 年第36 回応用物理学関係連合講演会 1 a X 4/III （2）山川他、1989 年第50回态用物理学会学術講演会 30 a Z L $1 /$ III

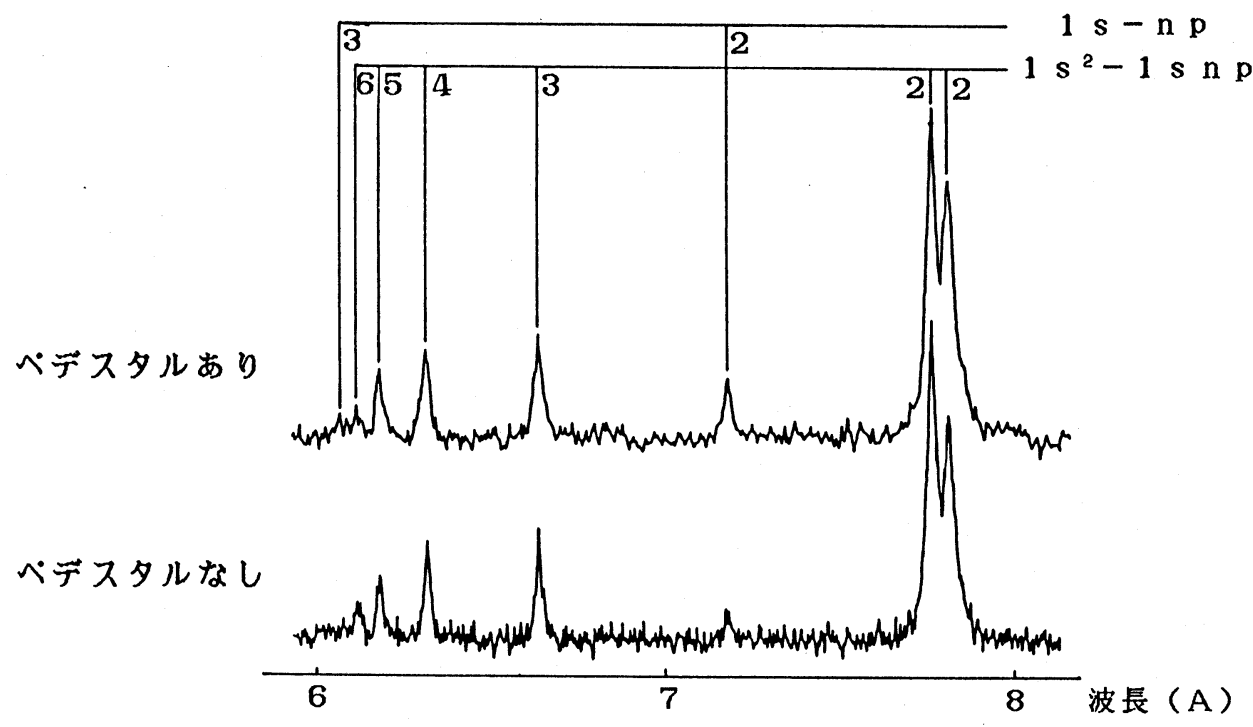

因1 A 1のX線スペクトル 


\section{6pI3 高繰返しレーザープラズマ X 線源}

大道博行、曾観明、戸川拓哉、金丙泰、金辺忠 ${ }^{\mathrm{A}}$ 、中塚正大、有留宏明 ${ }^{\mathrm{B}} 、$ 中井貞雄、

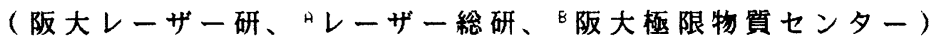

\section{1.はじめに}

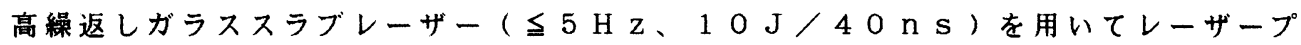
ラズマX線源の研究を行ってきた。レーザー光照射ターゲットとして回転ターゲットを 用いておりレーザーの高繰返し動作に対応しうるブラズマX線源が得られている。問題 点としては、Z I G Z A G 型スラブレーザーの繰返しを上げると（ $\geqq 1 \mathrm{~Hz}$ ) 集光性能 が劣化することが上げられる。い引き䌇き冾却性能の向上等、改良が必要である。この レーザー装置を用いX線リソグラフィー用マスク転写実験を行い最小露光間隔 0.25 $\mu \mathrm{m}$ が得られている。る

2.高繰返しスラブレーザーシステム

上記性能を有するZＩＧＺＡＧガラススラブレーザーを用い２種類のシステムを整備 している。第 1 はスラブレーザーをQースイッチ発振器として用いるシステムであり、 これまでX線リソグラフィイー等のプラズマX 線源発生用光源として用いられてきた。 課題は、集光性能を保って絽返し性能を向上すること、X 線変換効率向上のため $40 \mathrm{n}$

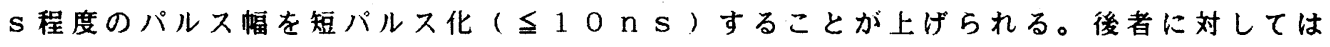
ポンピングエネルギー、Qースイッチのタイミング調整等で調節すること以外に可能和 色素によるパルス圧縮もテストしている。予備的な実験を開始しているK T P 結晶によ る 2 倍高調波変換と組み合わせるとX線変換効率が大きく改善されることが予想される。

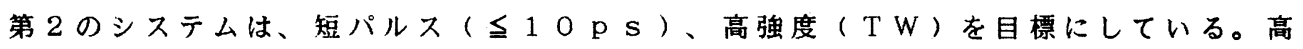
安定レーザー発振器からのパルス幅 $100 \mathrm{ps}$ 程度の光パルスを単一モード光ファイバ 一中に導き周波数チャープをかける。ふこのチャープのかかった光パルスをZ I G Z A Gアンプで增幅し、パルス圧編用グレーティングペアーに導くことにより上記光パルス が得られる。発振器からの光パルスをスラブアンプに導き增幅実験を開始したところで ある。

\section{3、レーザーブラズマX線源}

上記性能のレーザーが稼働しターゲット照射実験が可能になるとパルス幅（5 p s -

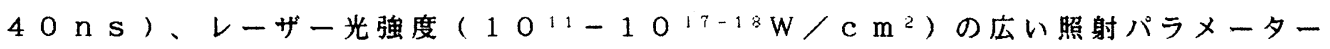
領域にわたりX線発生実験が高繰返しで可能になる。透過型回折格子分光器に加え、高 分解能( $0.1 \mathrm{~A})$ 反射型回折格子分光器をターゲットチェンバーに設置し定常的に実 験を行っている。

$\mathrm{X}$ 線源の応用として従来からのリソグラフィーに加え、X 線顕钽鏡用光源としてウオ 一ター空領域の高輝度極短パルスX線フラッシュの実現を目標とし研究を進めている。

\section{参考文献}

1) B. Kim et al. LEEE Photo Tech. Lett. Vol.2 Jan. issue (1990).

2) G. Zeng et al. to be published in J. Appl. Phys.

3) P. Maine et al. IEEE J. Quantum Electron. QE-24,398(1988). 
平成 2 年レーザー学会学術講演会第10回年次大会

26 p I 4

レーザープラズマ輻射による内殼励起レーザーの研究

( I )

理研、慶大理工 ${ }^{A}$ 渡部俊久 ${ }^{\wedge} 、$ 緑川克美、小原 實 ${ }^{A}$ 田代英夫

軟 X線〜 X U V の領域 $(0.1 \sim 100 \mathrm{~nm})$ に波長をもつ極短波長レーザーの実現は、V L S I のサブミクロ ン超微細加工など、様々な分野に重要な貢献を成し得るものとして大いに期待されており、今日盛んに研究 が進められている。この様な短波長レーザーの励起方式としては、電子衝突励起、電子再結合励起、光励起 などが挙げられる。なかでも光励起方式は、他の方式に比べ低密度のプラズマをレーザー媒質として用いる ことになるので、空間的密度勾配によるX線ビームの屈曲が深刻な問題とならないという点から有望視され ている。我々は、光励起方式による短波長レーザーの開発を目的として、これまでに、回転楕円体反射鏡を 用いた軟 X線集光系を開発してきた。今回は、X e - A u g e rレーザの基礎研究を目的として、この光学 系とスリットノズルを用いたパルスジェット装置を用いて、X e の吸収スペクトル、および軟 $\mathrm{X}$ 線励起によ るX e の蛍光スペクトルを観測した。

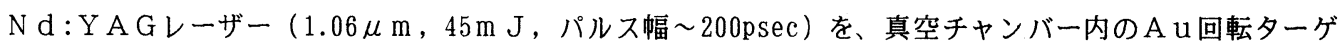
ットに強度〜 $10^{18} \mathrm{~W} / \mathrm{c} \mathrm{m}^{2}$ で集光し、生成したプラズマからの輻射軟 $\mathrm{X}$ 線を、回転棈円体反射鏡で、パ ルスジェットノズルより噴出するX e ガスに集光する。吸収スペクトルは、まず、 $\mathrm{X}$ e ガスを噴出させない ときのスペクトルを、光軸方向に設置した斜入射 X U V 分光器で測定し（Fig.1 (a))、次に、Xeガスを 噴出させたときのスペクトルを同様に測定して（Fig.1（b)）、Fig.1（a)とFig.1（b)との差から求めた

（Fig.1 (c))。なお、Fig.1 (a)〜 (c)の横軸のP C Dチャンネルナンバーは波長に対応しており、横軸の 1 は約 $140 \AA$ 、1024は $340 \AA$ Aである。Fig.1 (c)より主に $4 \mathrm{~d}$ 電子が光電離されているのがわかる。蛍光スペ クトルの測定は、光軸と垂直方向に設置したV UV 分光器 (Minuteman 302-VM) で分光した光をシンチレー 夕 (P-Terphenyl) で可視光に変換しP.M.T.で検出することによって行った。その結果、Fig.2に示すよ うにX e III $4 \mathrm{~d}^{18} 5 \mathrm{~s}^{8} 5 \mathrm{p}^{6}{ }^{1} \mathrm{~S}_{8}-4 \mathrm{~d}^{10} 5 \mathrm{~s}^{1} 5 \mathrm{p}^{5}{ }^{1} \mathrm{P}_{1}$ 遷移 $(108.9 \mathrm{~nm})$ 付近にピークが観測され た。

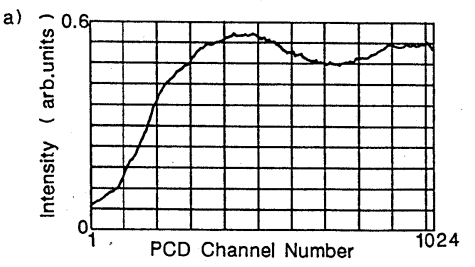

(b)

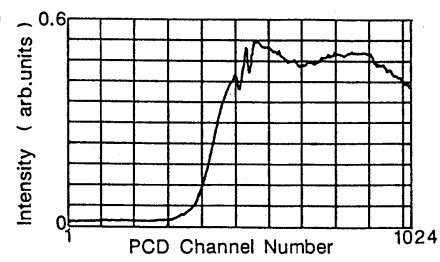

(c)

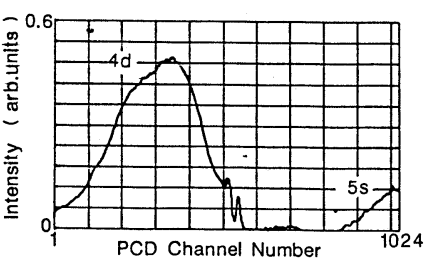

F i g. 1

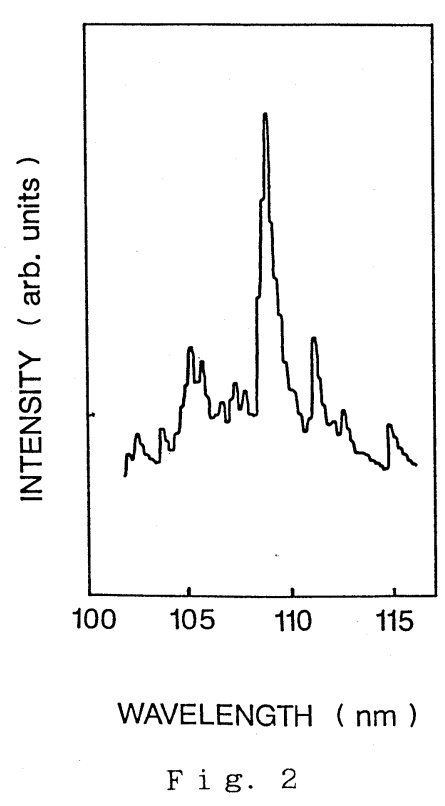




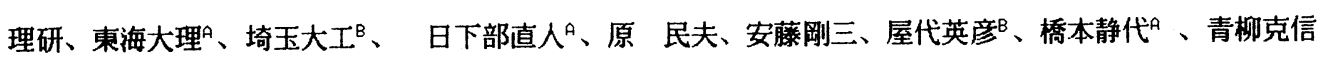

我々は、レーザー生成A 1 プラズマの再結合過程を用いた 軟X線レーザーの研究を行っている。

軟X線領域において、レーザー発振が期待される励起法に 再結合プラズマ法がある。従来の再結合プラズマ法では、お もにH样イオンが使用されてきたが、我々はより高い励起効 率が期待されるL i 様イオンに注目して研究を進めている。

実験装置を Fig.1 に示した。N d-ガラスレーザー ( $1.053 \mu \mathrm{m} 、 ハ ゚ ル ス$ 幅 $5 \mathrm{~ns})$ からのレーザービームは、シリンド リカルレンズにより A 1 ターダット上にラインフォーカスさ れる。そこでできた線状プラズマからの発光を、軸方向から フラットフィールドタイプの斜入射分光写真器により観測す る。プラズマの長さは、ターゲットチェンバーの外に設䜣た 調整板により変化させることができる。 プラズマの噴き出 し方向の分布は、トロイダルミラーによりスリット上に結像 するので、ターゲットを矢印の方向に移動することによりそ の分布を調べることができる。また、噴き出し方向に垂直な 分布む、写真乾板上に結像するので、スペクトル写真からそ の分布を調べることができる。

Fig.2 は、ターゲット表面から $0.8 \mathrm{~mm}$ 離れた位置での、プ ラズマ長Lが $12 \mathrm{~mm}$ と $3 \mathrm{~mm}$ のスペクトルである。このときの レーザーエネルギーは 2J である。A I X I 3d-5f (105.7A) をはじめ、合計 4 本のラインに増幅が観測された。利得は 3-4 $\mathrm{cm}^{-1}$ と非常に大きな值を示した。ここで注目すべきこと は、B e 様イオンのスペクトル線においても増幅が観测され たことである。さらに、プラズマ長が $12 \mathrm{~mm}$ と $6 \mathrm{~mm}$ のときの スペクトル線強度 I 1 、I 2 をターゲット表面からの距離を変 えてそれぞれ測定し、その比 $\mathrm{I}_{1} / \mathrm{I}_{2}$ から 利得 係数を計算 し利得の空間的掂がりについても調べた(このとき注目した ラインはA 1 X I 3d-4f (154.66A) である。)。

Fig.3 から、利得のプラズマ噴き出し方向への分布は、夕 一ダット表面から $0.8 \mathrm{~mm}$ のところを中心として半值幅で約 $350 \mu \mathrm{m}$ にわたって広がっていることが分かった。また、噴き 出し方向に垂直な方向の分布は、スペクトル写真加ら約 $600 \mu \mathrm{m}$ の拡がりをもって発光していることが測定され、この方向の利 得の搪がりも約 $600 \mu \mathrm{m}$ あることが分かった。以上のことから、 利得の空間的拡がりはターグット表面から $0.8 \mathrm{~mm}$ のところを 中心として $350 \times 600 \mu \mathrm{m}$ という非常に広い領域に分布してい ることが分かった。
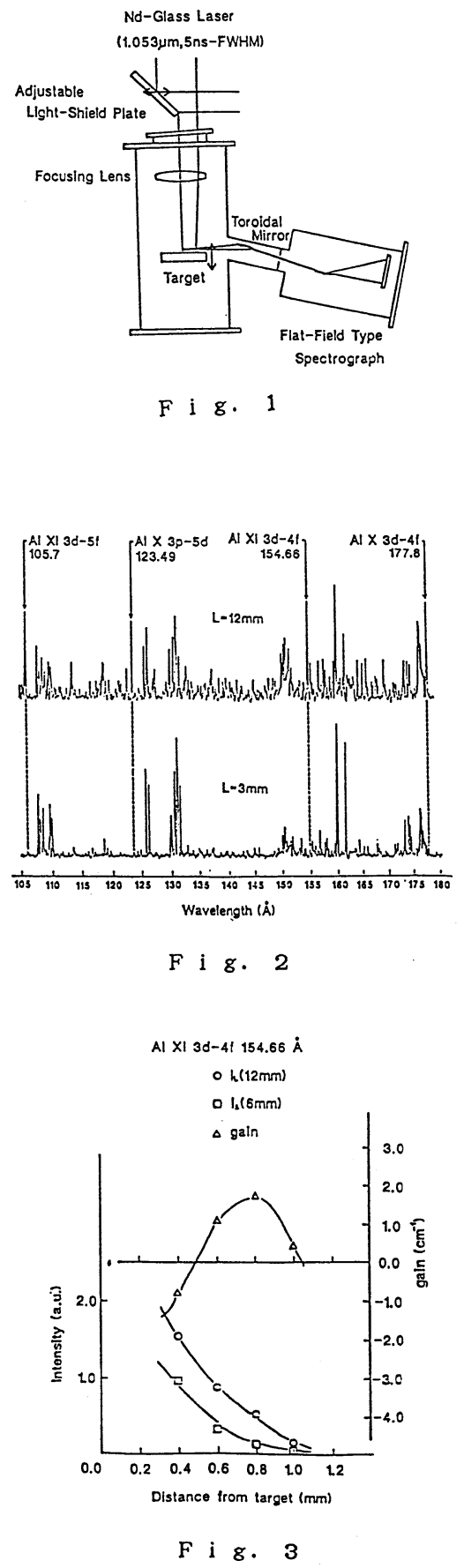
26pI 6 小型レーザー励起Siプラズマに出计为靯X線の增幅

理研、埼玉大学 (I) A、東海大学（理）B 屋代英彦、原民夫、安藤㴊三、

日下部直人 ${ }^{B} 、$ 井門俊治 ${ }^{A} 、$ 青柳克信

我々は小型レーザーを励起源としたレーザー生成ブラズマ中で再結合法を用いた軟X線 レーザーの研究を進めている。極最近までレーザー生成プラズマ中で軟X線の高い増幅作 用を得るには高密度多価イオンが必要不可欠であるとされてきた。このイオン密度の上昇 には大きなレーザーエネルギーによる照射を必要とし、主に核融合研究用励起レーザーを 用いて進められその增幅作用が確認されてきた。1しかし、大きな.レーザーエネルギーに よる照射は同時に電子温度の上昇を招き、再結合法で増幅作用を生じる低い電子温度の状 況は達成されにくい。我々は、必要最小限の強度のレーザーを非常に細い線状(約 $40 \mu$ m) に集光し電子温度の冷却効果を高めた実験を行ってきた。また、利得蝶質の長時間維持を 目的としターグットからプラズマを長い時間放出するために、ナノ秒パルス励起レーザー (5ns-FWHM)を用いた。

最初にA1 スラブターグットを用いた実験を始めその增幅作用を確認した。2)等電子数 配列において高 $Z$ 元素イオンはより短波長の発振線を得ることが可能であると期待される。 ここでは、A1より短波長の増幅作用が期待される S i ターダット物質として選択し実 験を行った。実駼装置の詳細は別件のA１ブラズマの增幅作用に記载されている。

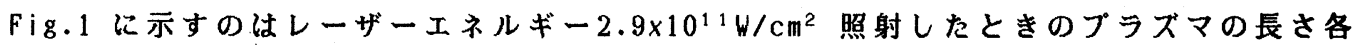
々 $11.5 \mathrm{~mm}$ (1 回露光)、 $5.7 \mathrm{~mm}$ (2 回露光)の S i プラズマのスペクトルを示す。これはブラ ズマの長さ $11.5 \mathrm{~mm}$ にいてレーザーエネルギー 6.6 」に相当する。钼测はターダット表面から約 $0.6 \mathrm{~mm}$ の位置で行った。この結果から、 L i 様、 B e 梯イオン遷移に打いて L i 様 $3 \mathrm{~d}-5 \mathrm{f}(88.84 \AA$ )小信号利得 $2.68 \mathrm{~cm}^{-1}$ をはじめとしていくつかの 透移において增幅作用を観测することができた。 通常、 B e 様イオン買移、 L i 様の方位量子数 の小さな $3 p-5 d$ 等の遷移では反転分布を生じに くく、この様な遷移においても增幅が観測され たことはプラズマの泠却が効率よく行われ反転 分布が生じたことを意味する。

今後、プラズマの媒質を長くしてょり強く増 幅された発光を観測するとともに、軟 $X$ 線鏡を 用いた共振器を設定しレーザー発振に向けて研 究を進めていく。

参考文献

1)D.L.Matthews et al. Phys. Rev. Lett. 54, 110 (1985)

2)T.Hara et al. Jap. J. Appl. Phys. 28,

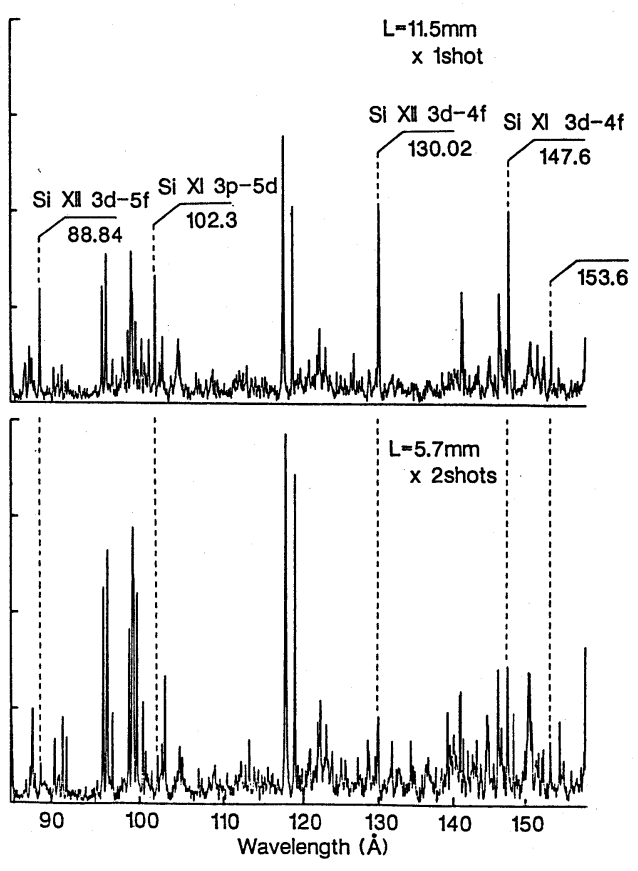

Fig. 1

L1010 (1989) 
平成 2 年レーザー学会学術講演会第10回年次大会

$26 \mathrm{p} I 8$

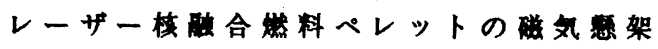

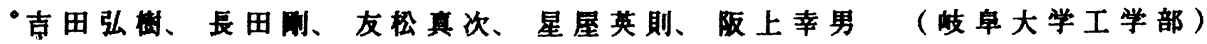

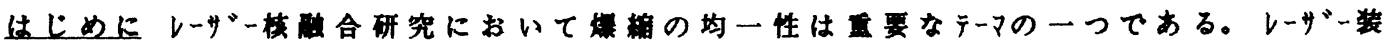

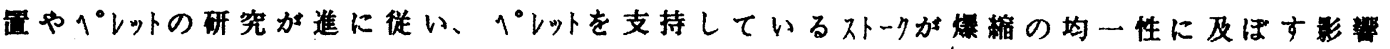

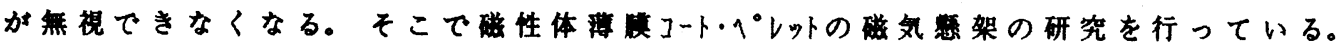

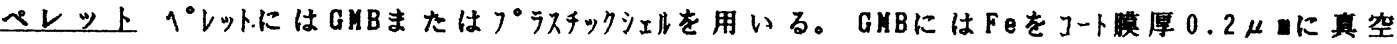

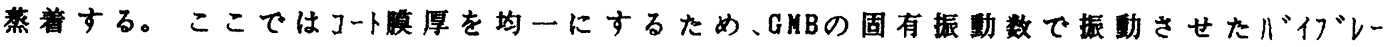

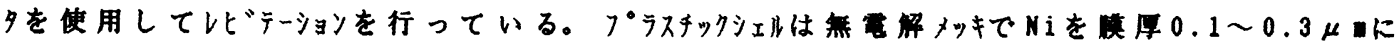

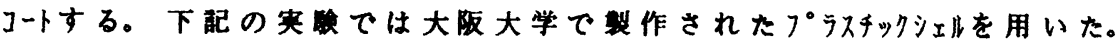

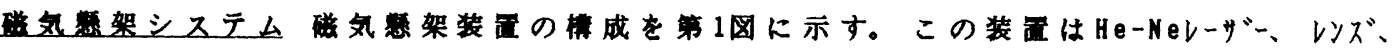

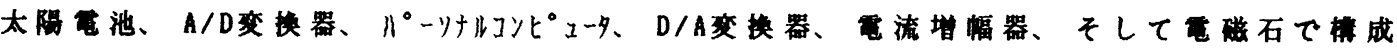

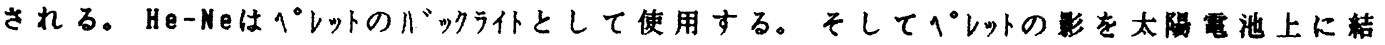

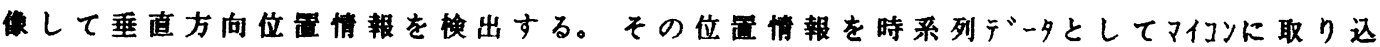
み、進み位相㭪供を行って、電磁石を殹的する。

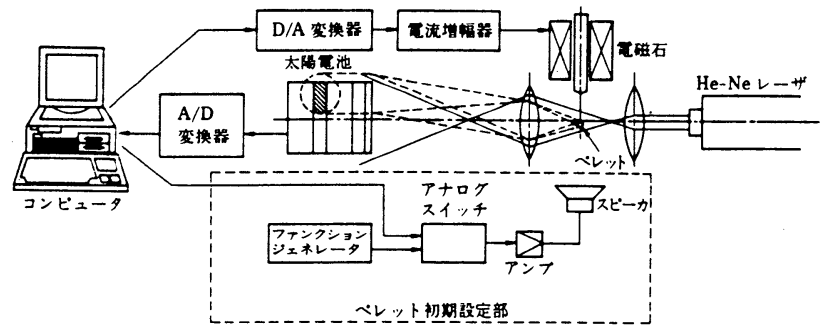

第1圀磁気愁架システムの椿成 マにチビームレーザーによる実毁では電磁石の占有出来る 空間が限定される。そこでレ゙ザーのフォーかス・ス訳怗ら

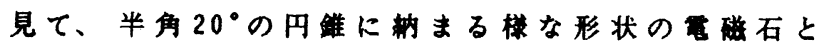
して困2に示すものを製作した。㭪助磁は磁束の

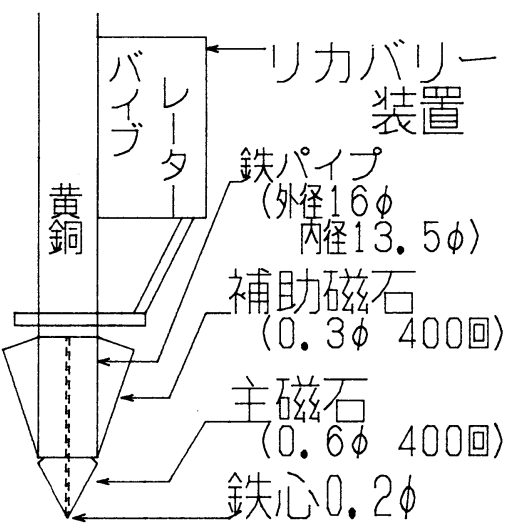
発散を押え主璔先端部の碳束密度を高める。

またシステムとしての信頼性を向上させるために 第 2 图勧磁石と师川゙リー置

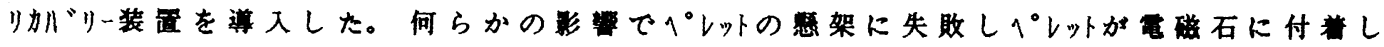
てしまった場合、電磁石の電流を切り、電磁石を微小振亜させげレットを回収する置て

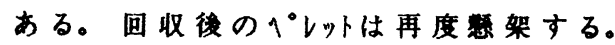

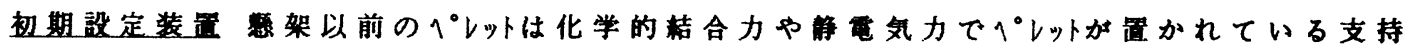

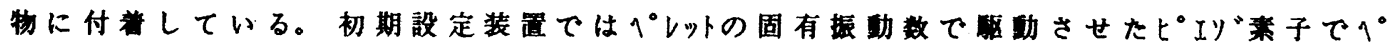

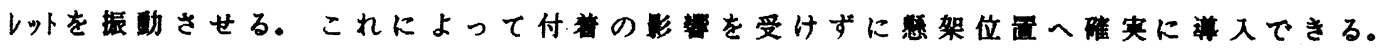

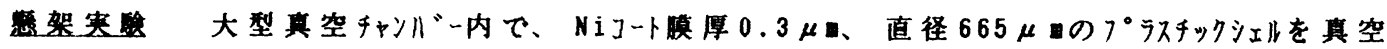

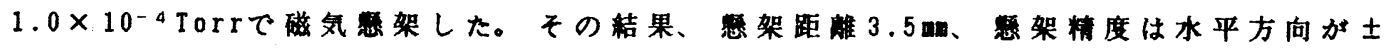

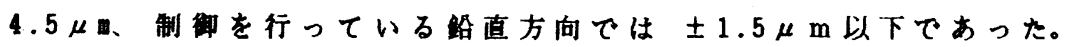


平成 2 年レーザー学会学術講演会第10回年次大会

26pＩ９「M e d u s a」コードによるK r Fレーザーとプラスマの相互作用の考寮

電通大新形レーザー 佐々木明、押鐘寧、米田仁紀、植田憲一、宅間宏

(はじめに) 波長 $249 \mathrm{~nm}$ ～K r Fレーザーは、慣性核融合用エネルギードライバーとして、 ターゲットプラズマの吸収率が高く、高いアブレーション圧力が得られ、間接照射において重 要な高いX線への変換効率が得られる利点を持つ反面、熟的スムージングが起こりにくいため にレーザー光の照射不均一性の影響を受けやすい欠点を持つとされている。一方プラズから の軟X線放射特性は、ターダット内の輻射によるエネルギー輸送、X線レーザーの動作を明ら かにする上でも重要である。われわれは、これらの課題を長パルス（～10 ns）およびピコ秒 フロントエンド発振器を持つ出力 $500 \mathrm{~J}$ 級電子ビーム励起 Kr Fレーザーシステムを用いた 実験と、計算機シミュレーションによって調べている。本講演ではこのための流体および原子 過程のシミュレーションと、その結果について述べる。

（流体モデル）まずKrFレーザー照射プラズマの基本的な特性を明らかにするために、1 次 元、2 温度 1 流体ラグラジアンシミュレーションコード「M e d u s a」1を用いた計算を行 なっている。(四 1 )にDーTターダット(初期密度 $0.18 \mathrm{~g} / \mathrm{cm}^{3}$ ) を強度 $10^{14} \mathrm{~W} / \mathrm{cm}^{2}$ の レーザー光で照射し、照射開始後 $5 \mathrm{~ns}$ (フラットトップパルス）の温度、密度分布の武算桔果 を示す。カットオフ密度が高い短波長レーザーはブローオフ領域から密度勾配が急峻なテフラ グレーション領域まで進入する。（図２）は古典吸収による吸収パワー密度の分布であるが、 吸収がデフラグレーション領域で集中して起こることが示されている。このような条件のもと での共鳴吸収や非線形効果の寄与についても検討を行なっている。

（原子モデル） A 1 プラズマ中の軟 X 線放射を、 $\mathrm{H}$ 様、 $\mathrm{H}$ e 様、 $\mathrm{L}$ i 様イオンの基底状態と主 要な 12 種の励起状態の、電子衝突電離、3 体再結合、電子衝突励起 ·脱励起、光励起、自然 放出、光電離、故射再結合、2 重電子再結合の諸過程を取り报うCollisional-Radiativeモデル2に よる原子過程のシミュレーションを行なって調べている。「M e d u s a」コードで求められ たプラズマのパラメータを原子モデルにあてはめて、イオンの価数、励起状態への分布、線ス ペクトルおよび連続スペクトルのX線放射の振舞いを調べて報告する予定である。

1) J.P.Christiansen, et al. Comput. Phys. Commun. 7,271(1974).

2) M.Itoh, et al. Phys. Rev. A 35 , 233(1987).

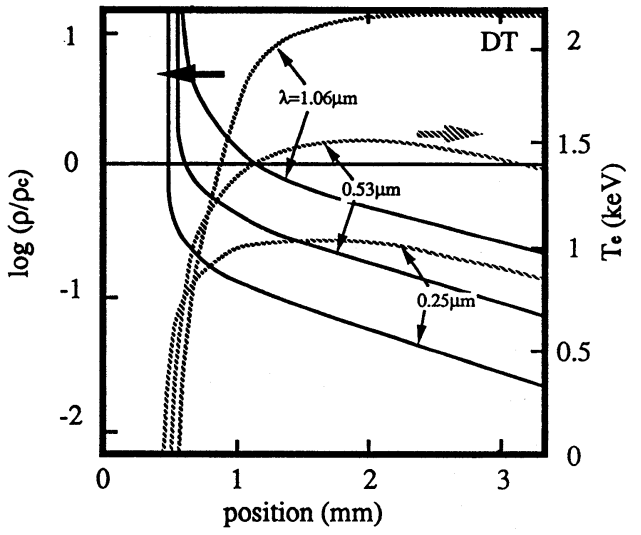

(困 1)

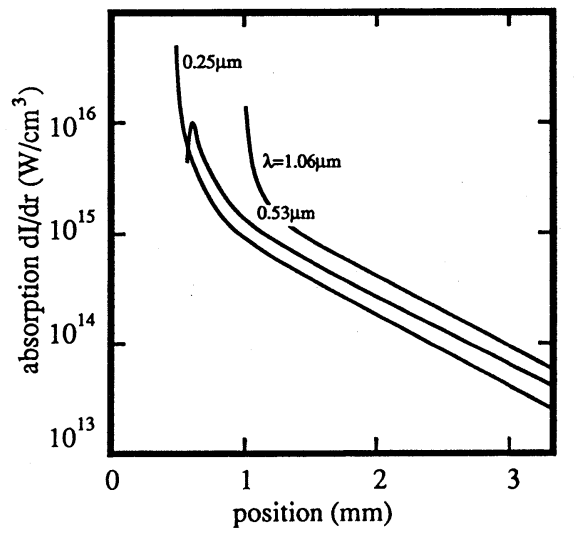

(困2) 
阪大レーザー研

中石博之、宮永㲅明、畦地宏、節原裕一、片山誠

高木勝、実野孝久、西口彰夫、三間圆興、中井貞雄

慣性核融合研究においては、固体密度の数百倍から数干倍 の高密度プラズマを爆縮により生成することが必要である。 このような高密度プラズマの診断技術がここ数年で急速に進 歩し、高密度圧縮に必要なターグット、レーザー照射条件が プラスチックシェルターグットの爆縮により明らかにされつ つある。

図 1 は、中性子放射化法 ${ }^{\prime}$ にって得られた压縮コアの密 度と、初期ターグットサイズとの関係を示している。ランタ ムフェーズプレートを使用して照射均一性を向上させること により、通常のレーザー光照射に比べて、圧縮密度が 1 桁近 く高くなることが実験によって示された。達成された最高圧 縮密度は、初期密度 $\left(1 \mathrm{~g} / \mathrm{c} \mathrm{m}^{2}\right)$ の 600 倍程度である。 図 2 は、ランダムフェーズプレートを用いた照射の際の集 光条件と圧縮密度及び発生中性子数の実験結果を示したもの である。本来のランタムフェーズプレートの理想的な集光条 件 $\mathrm{d} / \mathrm{R}=0$ に近づけてゆくと $\mathrm{d} / \mathrm{R}=-4$ の付近で急に圧 縮率が低下してしまうため、エネルギー的には不利である $\mathrm{d} / \mathrm{R}=-5$ という条件で実験を行った。

ターグットには、S i の放射化による面密度計測を可能に するために開発された、C D T S i プラスチックシェルを使 用した。C、DおよびS i は、化学的な合成によって含有さ れているものであるが、トリチウム（T）は、UV光を利用 した光励起同位体交換反応によってターゲット中に組み入れ られている。図3は、用いた夕ーグットの干涉顕微鏡写真で ある。真球度、及び壁厚の不均一性は $2 \%$ 以下のものが得ら れている。このターゲットを支持するためにこれまでは $7 \mu \mathrm{m}$ 程度のポリエステルファイバーが用いられていたが、さらに これより細い2.5 $5 \mu \mathrm{m}$ のボリエステルファイバーが試みら れた。ほほ同等の実験条件で比較すると、明らかに圧縮率の 向上がみられている。

詳細は講演に挔る。

1)E.M.Campbell et. al.,J. Appl. Phys. 51,6062(1981).

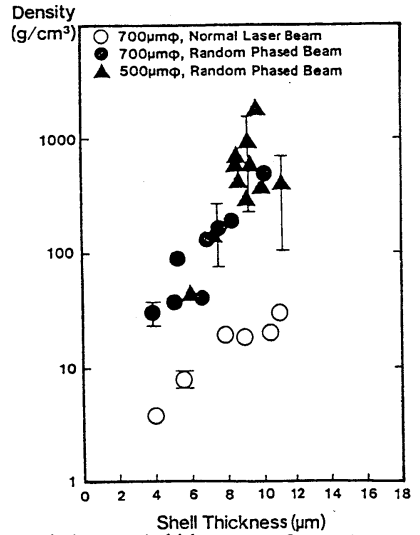

図 1.圧縮コアプラズマ の密度

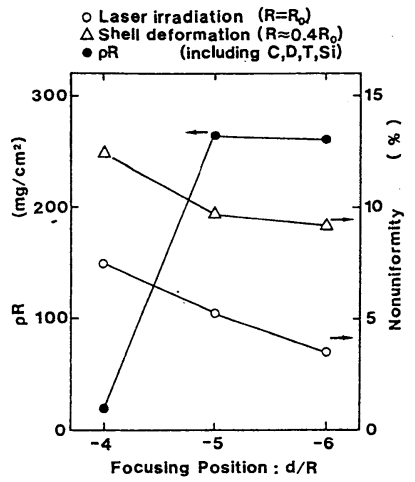

図 2. 集光条件と面密度

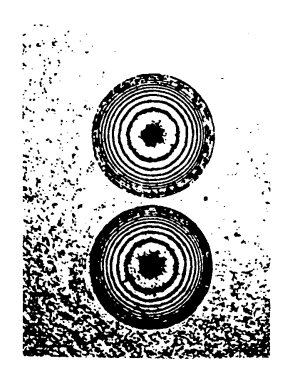

図 3. C D T S i シェル 
平成 2 年レーザー学会学術講演会第10回年次大会

\section{6p I11 Foam-cryogenic D2 Target Implosion I}

\section{-Implosion Characteristics by X-ray Spectroscopy-}

P. Zeller, K. A. Tanaka, T. Norimatsu, M. Nakai, T. Kanabea, H. Katayama, R.

Kodama, D. Vick, M. Katayama, M. Kado, M. Tsukamoto, H. Kiyama, K. Nishihara,

T. Yamanaka, C. Yamanakaa, S. Nakai, T, M, and GOD Groups

Institute of Laser Eng., Osaka Univ., Institute for Laser Technologya

Foam-cryogenic spherical targets doped with a small amount of silicon were imploded using the $8 \mathrm{~kJ}$ Gekko XII laser of ILE. Si emission lines were recorded using a time-integrated spectrally resolved crystal spectrograph. The $30 \mu \mathrm{m}$ wide entrance slit of the spectrograph provides a one-dimensional image of the target with a magnification of 5.3. A microdensitometer trace of this image at the Ly $\gamma$ wavelength is shown in Fig. 1. The diameter of the emitting region, measured as the FWHM of the peak on Fig. 1 , is $2 \mathrm{R}=87 \mu \mathrm{m}$. The Ly $\gamma$ microdensitometer trace is plotted in Fig. 2. The FWHM of Ly $\gamma$ is measured as $33.5 \mathrm{~m} \AA$. The wavelength scale on the film being equal to $174 \mathrm{~m} \AA / \mathrm{cm}$, the instrumental imploded core at $4.95 \AA$ (Ly $\gamma$ ) broadening due to the target size $2 \mathrm{R}$ amounts to 1.5 $\mathrm{m} \AA$. The Doppler broadening is very small; an estimate at a temperature of $1 \mathrm{keV}$ is $2 \mathrm{~m} \AA$. Though the temperature is not known precisely, the broadening dependence is only on the square root of the temperature, which reduces the uncertainty. The remaining $30 \mathrm{~m} \AA$ are attributed to the Stark broadening. In the assumption of broadening by the $\mathrm{D}+$ ions, the Holtzmark formula yields an electron density of

$$
\mathrm{N}_{\mathrm{e}}=5.6 \times 1022 \mathrm{~cm}-3
$$

and thus a mass density $\rho=0.19 \mathrm{~g} / \mathrm{cm}^{3}$ and an areal density $\rho R=0.83 \mathrm{mg} / \mathrm{cm}^{2}$. The areal density was also measured using a secondary neutron detection technique and the result was $2.1 \mathrm{mg} / \mathrm{cm}^{2}$. The origin of this discrepancy is currently being examined.
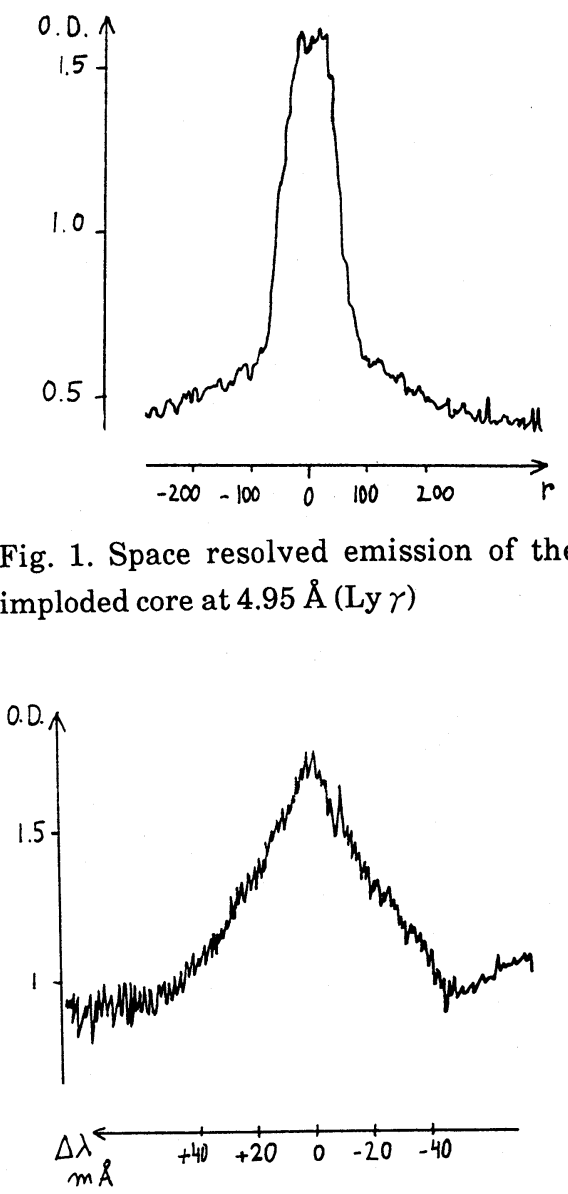

Fig. 2. Microdensitometer trace of the $\mathrm{Si}+13 \mathrm{Ly} \gamma$ line emitted by the imploded target. 
平成 2 年レーザー学会学術講演会第10回年次大会

$26 \mathrm{p} I 12$

フォームクライオターグット中でのエネルギー輸送

阪大レーザー研児玉了祐田中和夫垂松孝好中井光男片山秀史片山誠 レーザー総研 ${ }^{\mathrm{A}}$ 加道雅孝塚本雅裕金辺忠 ${ }^{\mathrm{A}}$ 西原功修山中龍彦

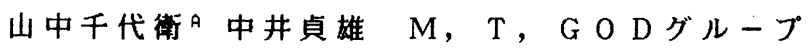

現在、レーザー核融合における臨界用高効率ペレットを目指した低原子番号、 低密度のフォームクライオジェニックターグット（CHフォームシェルに液体 $\mathrm{D}_{2}$ を浸透、固化させたペレット）が開発され爆縮実験が行われている。ところが微 細拲造を持った低密度ターグットにおけるエネルギー輪送の詳細に付いて実験的 に十分調べられていない。本講演では、このフォームクライオターゲット中での エネルギー輸送に関する実験結果を報告する。

実験はレーザー光を平板フォームクライオターダットに照射し、その後面発光 をU V 領域、及びX 線領域で波長あるいは空間、時間分解計测した。その結果、 レーザーアブレーションによる街揧波加熱と高エネルギー電子による先眍加熱を 時間的に分類して测定することが出来た。図1は、各加熱機構によるターゲット 後面温度のターグット面密度依存性を示したものである。衝撃波加熱による後面 温度は夕ーグット面密度にほとんど依存していないのに対し、先駆加熱はターゲ ットの厚さに対して指数関数的依存性を示している。これは、熱電子分布関数の 高エネルギ一成分あるいは、非線形相互作用による高エネルギー電子等の非局所 的エネルギ一輸送によると考えられる。非線形相互作用と先釦加熱を同時に時間 分解計測することにより、それらの時間相関も求めている（図 2 ）。また、レ一 ザ一照射面に、より高い原子番号の材質をコートすることにより衝撃波加熱及び 電子による先聑加熱を1/2に低減させることが出来た。さらにレーザーパルス 波形成形による衝撃波加熱及び電子による先剾加熱への影響も調べている。

詳細は本講演にて述べる。

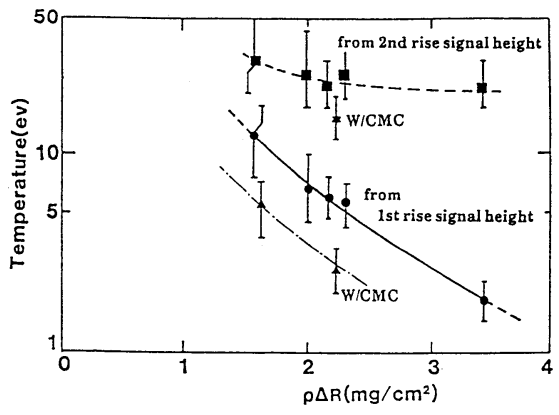

図 1
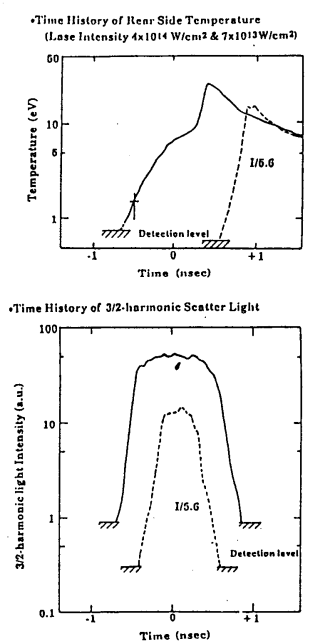

図 2 
平成 2 年レーザー学会学術講演会第10回年次大会

26p I 13 激光 X II 号ブルーレーザーによる軟X線輻射駆動型キャノンボール爆縮

阪大レーザー研 白神宏之, 西村博明, 遠藤琢磨, 近藤公伯, 片山誠, 杉本耕一, 小林尚志, 高部英明, 加藤義章, 中井貞雄、 G O D , O T, T, Mグルーブ

軟 X線輻射駆動アブレーションを用いたキャノンボールターゲットの爆縮について、爆縮一-样性の制御と高密 度爆縮に関する研究を行っている。

実験にはガラスレーザー激光 X II 号 3 山光出力 $6 \mathrm{k} \mathrm{J} / 0.8 \mathrm{n} \mathrm{s} \cdot 10$ ビームを使用した。キャノンボール ターゲットではキャビティ内のA uブラズマのためこれまて観測が困難であった爆縮ダイナミクス計測に関して いくつかの新たな試みを取り人れた。D T燃料の代わりにArを充填したブラスチックシェルを使用し、X線フ レーミングカメラにより爆縮コア形状の時間変化を、タイムマーカーを入れたX線ストリークカメラにより爆縮 絶対時刻を測定した。また、T i ターゲットを使用することにより、高エネルギー (4.8k e V) 単色X線バ ックライト法を導入し、X線フレーミングカメラと組み合わせて爆縮途中の燃料ペレットの動きを観測した。こ れらの新計測手法により爆縮速度、爆縮一样性、爆縮コア形状などが観測可能となった。

爆縮一样性とレーザー照射位置の関係をモデル計算により評洒し、実駼結果と比較した。その結果、レーザー 照射位置は爆縮コアの非一样性（特にモード数 2 及び 4 ）に大きく影響を与えることが明らかとなり、ターゲッ 卜設計およびレーザー照射配位の検討に高精度が要求される事になった。レーザー照射配位によりこれらの非一 様性は制御可能であることが実験的に示された。

達成される半径圧縮率によっても爆縮一样性を評洒するため、充填燃料ガス圧力およびアブレータ一潒の厚さ を変化させて爆縮実験を行った。半径圧縮弯は $\mathrm{R} 0 / \mathrm{Rf} \sim 20$ 程度が実現できており、爆縮一样性は少なくと も5\%程度までは達成されていると言える。

爆縮コアバラメーターは上記実験に打いて平行して測定された。燃料 $\rho \mathrm{R} \sim 10 \mathrm{mg} / \mathrm{cm}^{2}$ 、燃料密度は個 体密度 $\times 20$ 倍が達成された。さらに密度を向上させる計画である。

計算機シミュレーションコード開発も平行して進めら机ており、特にキャビティ内おっびアブレーション過程 でのX線輻射輪送の取り扱いに関して改善を行っている。また、2次元コードについても開発が進んでいる。 